\title{
Identifikasi Nilai Kemajemukan Indonesia sebagai Identitas Bangsa dalam Iklan Mixagrip Versi Keragaman Budaya
}

\author{
Rustono Farady Marta ${ }^{1}$ dan Jean Sierjames Rieuwpassa ${ }^{2}$ \\ ${ }^{1}$ Universitas Bunda Mulia \\ ${ }^{2}$ Sekolah Tinggi Filsafat Theologi Jakarta
}

\begin{abstract}
ABSTRAK
Kreativitas manusia dalam produk ciptaannya berkaitan erat dengan budaya, karena kebudayaan adalah sarana bersemainya cipta, rasa, dan karsa manusia. PT. Kalbe Farma, Tbk (Kalbe) melalui produk Mixagrip berusaha mengapresiasi kekayaan budaya di Tanah Air, mulai dari kegiatan kampanye "Mixagrip, Explore Budaya Indonesia", dilanjutkan "Gowes Pesona Nusantara" dan "Mixagrip Cinta Budaya Sehat". Seluruh kegiatan tersebut ditujukan kepada berbagai daerah di Indonesia, setidaknya terdapat sebelas kota disasar oleh berbagai kampanye tersebut. Selain itu, terpaan nasional diramaikan pula dengan kemunculan iklan versi "Keragaman Budaya Indonesia". Keunikan iklan Mixagrip yang mengetengahkan Laudya Cynthia Bella sebagai brand ambassador ini, terletak pada upaya mengakomodasi berbagai budaya daerah nasional ke dalam sebuah iklan. Bersandar pada analogi enam dimensi kultural yang dicetuskan oleh Geert Hofstede, maka temuan penulis pada iklan Mixagrip tersebut dielaborasi dengan metode analisis konten kualitatif Phillip Mayring. Penelitian ini akan dipijakkan pada paradigma interpretif untuk menemukan tiga elemen utama analisis konten kualitatif Mayring, antara lain: abstraksi, eksplikasi, dan strukturasi. Ketiga tahapan ini diidentifikasi penulis sebagai nilai kemajemukan Indonesia, sekaligus mengimplementasikan semboyan nasional "Bhinneka Tunggal Ika". Kepentingan bisnis yang umumnya disematkan melalui suatu produk iklan Television Video Comercial (TVC), seketika dialihkan kepada kepedulian akan toleransi kemajemukan budaya yang sedang ditumbuh kembangkan oleh pihak Mixagrip dalam konsep berbagi "kasih" dan bersikap "epoche".
\end{abstract}

Kata-kata Kunci: Analisis konten mayring; budaya; dimensi kultural hofstede; iklan mixagrip; kemajemukan

\section{Indonesian Pluralism Value Identification as Nation Identity in Mixagrip Advertising Version of Keragaman Budaya}

\begin{abstract}
Human creativity embodied in the product creation is closely related to culture, because culture is the conductor of creation, taste, and human initiative. PT. Kalbe Farma, Tbk (Kalbe) through Mixagrip products try to appreciate the richness of Indonesian culture, starting from "Mixagrip, Explore Budaya Indonesia", "Gowes Pesona Nusantara" and "Mixagrip Cinta Budaya Sehat". All activities are addressed to various regions in Indonesia, there are at least eleven cities targeted by those various campaigns. In addition, the national exposure was also enlivened with the ad of the "Keragaman Budaya" version. The uniqueness of the Mixagrip advertisement that features Laudya Cynthia Bella as the brand ambassador, lies in the effort to accommodate various national regional cultures into an advertisement. Relying on a six-dimensional cultural analogy coined by Geert Hofstede, the authors'findings on the Mixagrip ad are elaborated with qualitative content analysis methods Phillip Mayring. This research will be grounded in the interpretive paradigm to find three main elements of Mayring's qualitative content analysis, including: summary, explication, and structuring. These three stages are identified by the author as Indonesian pluralism, as well as implementing the national motto "Bhinneka Tunggal Ika". The business interests that are generally embedded through a Television Video Comercial (TVC) advertising product, are instantly diverted to the concern of tolerance of cultural diversity that is being grown by the Mixagrip in the sharing concept of "love" and "epoche" attitude.
\end{abstract}

Keywords: Advertisement; culture, hofstede cultural dimension; mayring content analysis; mixagrip; pluralism

Korespondensi: Dr. Rustono Farady Marta, S.Sos., M.Med.Kom. Universitas Bunda Mulia. Jln. Lodan Raya No.2, Jakarta Utara 14430.Email: rmarta@bundamulia.ac.id 


\section{PENDAHULUAN}

Perkembangan zaman menggiring manusia pada era yang kompetitif, sehingga kreativitas dalam menciptakan ide-ide dan karya baru menjadi tuntutan utama. Salah satunya diterapkan dalam mengemas pesan persuasif dan kontekstual, kemudian pesan tersebut diimplementasikan pada berbagai kegiatan maupun media promosi produk tertentu. Salah satunya yang dilakukan PT Kalbe Farma Tbk (Kalbe), pada Hari Minggu 06 Agustus 2017 meluncurkan kampanye "Mixagrip, Explore Budaya Indonesia". Bersamaan dengan itu digelar pula kegiatan "Gowes Pesona Nusantara" yang diikuti oleh 5000 peserta, dengan titik awal kumpul di Lapangan Pondok Pinang mengawali rute bersepeda menuju Bungur Raya, Kantor Walikota Jakarta Selatan, dan Taman Ayodia.

Selain itu, Mixagrip juga mengajak segenap masyarakat Indonesia ikut mengekspresikan kecintaan pada budaya nasional melalui kontes foto. Puncaknya kegiatan ditutup pada bulan Oktober di Kawasan Danau Toba, Pulau Samosir Provinsi Sumatera Utara. Kegiatan ini melibatkan lebih dari 20.000 peserta dari sebelas kota antara lain: Banjarmasin, Serang, Jakarta, Bekasi, Depok, Bandung, Cirebon, Surabaya, Yogyakarta, Lamongan dan Semarang. Adapun tagline yang diusung untuk menyukseskan acara puncak tersebut adalah "Toba Samosir, Serpihan Surga Danau di atas Danau", melalui berbagai kanal media sosial seperti Facebook Mixagrip Cocok, Twitter dan Instagram @ mixagripcocok, serta disosialisasikan pula pada situs resmi www.mixagrip.com dan www.kalbe. co.id.

Melihat fenomena penyebaran informasi kesehatan di masyarakat yang demikian marak seperti halnya yang dilakukan Kalbe melalui promosi produk Mixagrip, maka iklan yang ditayangkan kepada khalayak pemirsa juga dituntut untuk menciptakan sebuah pariwara yang memiliki beragam aspek. Iklan tidak lagi bertujuan hanya berisi pesan untuk sekedar promosi profil dan khasiat produk pengobatan kesehatan, namun diharapkan mampu pula menampilkan hal yang lebih dari sekedar pesan ekstrinsik. Seperti pesan yang tersirat pada Iklan Mixagrip, dimana tersaji ragam identitas budaya daerah Indonesia sebagaimana representasi dari negara yang memiliki kultur majemuk.
Iklan Mixagrip menjadi salah satu karya dan memiliki nilai jual yang tinggi. Umumnya iklan salah satu merek obat flu menyasar para konsumen yang mendambakan hidup sehat, mengingat begitu kompleksnya masalah kesehatan dengan segala seluk beluknya dan hidup sehat menjadi dambaan setiap orang. Di sisi lain, kemajuan teknologi komunikasi serta kepemilikan sarana tersebut di masyarakat mengakibatkan informasi masalah kesehatan mudah diperoleh (Hidayat, 2014).

Dalam rangka memperingati hari jadi ke-38 tahun produk Mixagrip menemani masyarakat Indonesia, maka tidak hanya kampanye maupun iklan yang coba disuguhkan melainkan juga brand ambassador. Menghadirkan salah seorang artis muda berbakat Indonesia yang melejit namanya di usia 29 tahun, yakni Laudya Cynthia Bella. Lebih dari satu dekade kariernya membintangi berbagai sinetron di televisi maupun film layar lebar, hasil yang membanggakan di dunia perfilman Tanah Air ditunjukkan dengan prestasi meraih sepuluh penghargaan berhasil diperolehnya sejak debutnya di film berjudul "Virgin" pada tahun 2005 hingga 2016. Kepiawaian Laudya berperan di berbagai film mampu merepresentasikan keterampilannya dalam mengakomodasi berbagai situasi dengan latar budaya yang berbeda.

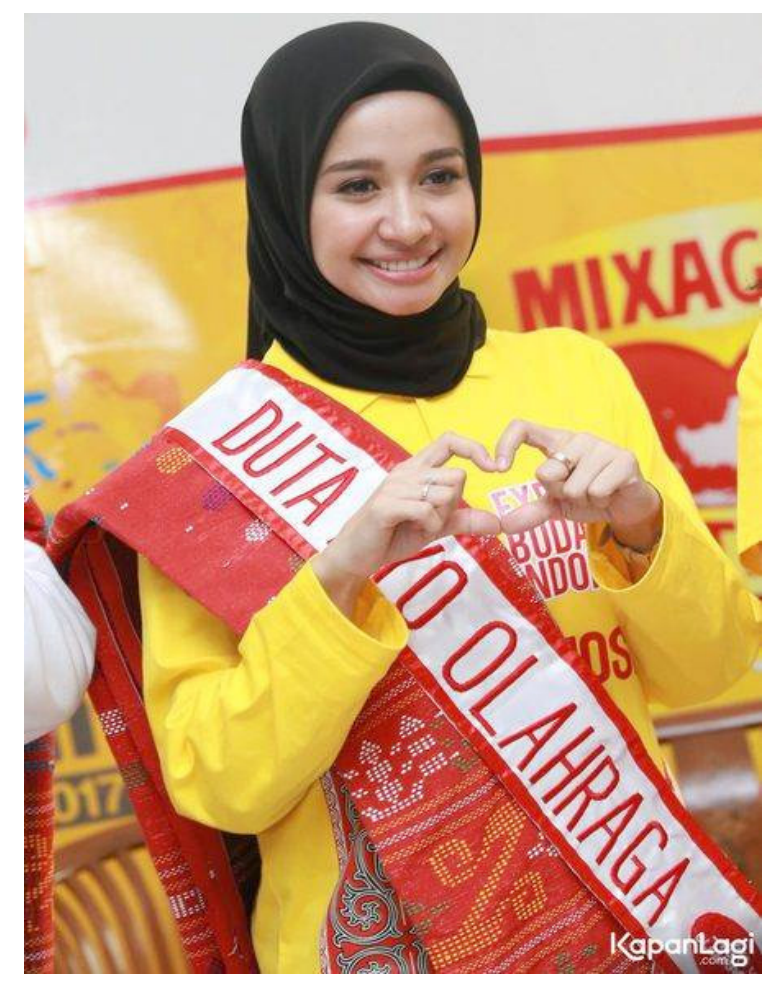

Sumber: Srikhandi, 2017

Gambar 1 Laudya Ambassador Mixagrip 
Perpaduan antara ragamkegiatankampanye, iklan Television Video Commercial (TVC), dan kehadiran brand ambassador menjadi kekuatan merek. Hal ini yang menjadi keunggulan Mixagrip dalam meraih brand awareness di benak khalayak konsumen. Selain itu dimensi yang disasar tidak hanya aspek budaya, terlihat melalui selempang yang dikenakan Laudya pada Gambar 1 yang bertuliskan Duta Ayo Olahraga. Slogan ini seiring semangat yang dihembuskan melalui serangkaian kampanye "Mixagrip Cinta Budaya Sehat". Dalam rangka memperkuat pesan kampanye tersebut, dilekatkan pula misi meningkatkan produktivitas seluruh masyarakat Indonesia melalui ajakan melakukan kegiatan positif, salah satunya berupa eksplorasi kekayaan budaya nasional.

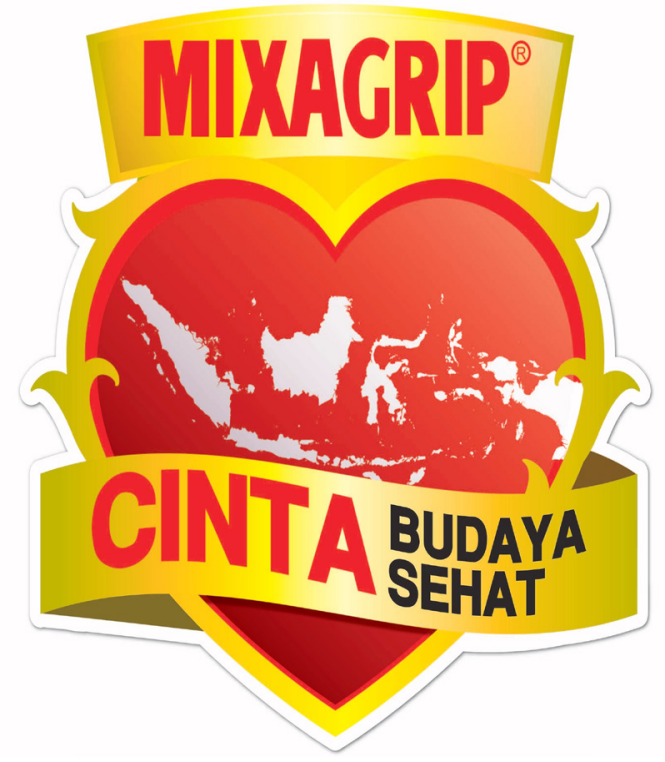

Sumber: Mixagrip Cocok, 2016

Gambar 2 Logo Kampanye Mixagrip

Kekayaan budaya daerah Indonesia telah menjadi pesan utama yang ditampilkan di scene awal iklan Mixagrip ditayangkan, dimulai dengan memperlihatkan semacam pagelaran atau festival budaya daerah di Indonesia. Dalam festival tersebut berbagai macam budaya dan karya anak bangsa diperlihatkan, mulai dari Batik Jawa, Tari Saman, dan Pencat Silat. Tidak hanya itu, dalam iklan tersebut juga diperlihatkan kostum yang dikenakan oleh para pemeran menggunakan berbagai macam pakaian adat Indonesia (Jawa, Kalimantan, Bali, Sumatra, Papua). Meski belum semua seni dan budaya daerah di Indonesia terakomodir dalam iklan tersebut, namun secara keseluruhan pesan yang ingin ditonjolkan adalah keberagaman kebudayaan Indonesia.

Budaya dan komunikasi mempunyai hubungan yang sangat erat. Manusia berkomunikasi sesuai dengan budaya yang dimilikinya, kapan, dengan siapa, berapa banyak hal yang dikomunikasikan sangat bergantung kepada budaya dari individu yang melakukan interaksi. Aspek-aspek budaya dalam komunikasi seperti bahasa, isyarat, non verbal, sikap, kepercayaan, watak, nilai dan orientasi pikiran akan lebih banyak ditemukan sebagai perbedaan besar yang sering kali menyebabkan distorsi dalam komunikasi. Namun, dalam masyarakat yang bagaimanapun berbedanya kebudayaan, tetaplah akan terdapat kepentingan-kepentingan bersama untuk melakukan komunikasi (Alex, 2001).

Jika ditelaah dengan baik, komunikasi yang dilakukan oleh artis utama sebagai salah satu motor penggerak yang diberikan tanggung jawab untuk menyampaikan pesan iklan Mixagrip kepada khalayak bahwa Indonesia pada dasarnya adalah negara majemuk, tetapi ada nilai kehidupan yang menarik untuk dikaji. Dalam iklan tersebut, sang artis dengan lantang mengatakan

"dari Sabang sampai Merauke, kita punya budaya yang berbeda-beda. Kalau untuk flu dan batuk, kita punya satu kesamaan" diucapkan oleh artis Laudya Cynthia Bella (2017).

Pernyataan tersebut menarik untuk dikaji, bahwa melalui sebuah produk dapat menunjukkan nilai nasionalisme yang ingin ditanamkan bagi khalayak. Meski terlalu utopis untuk mengatakan bahwa iklan ini merupakan bagian dari kecintaan akan Tanah Air, namun tidak dapat dipungkiri bahwa hal tersebut telah terkandung dan bersifat esensial dari iklan yang disajikan.

Dalam menganalisis iklan Mixagrip ini, penulis menggunakan enam dimensi yang dipaparkan oleh Geert Hofstede (2010) untuk menjadi pisau bedah dalam rangka melihat iklan tersebut sebagai sarana memperkenalkan budaya dan kemajemukan Indonesia. Hofstede merupakan tokoh yang cukup berpengaruh dalam bidang kajian budaya lintas disiplin, karena buah pikirannya dapat memperlihatkan bahwa budaya tidak dapat terelakkan dari proses komunikasi yang setiap harinya dilakukan oleh 
manusia.

Salah satu bentuk penyadaran Hofstede bahwa setiap negara dan tempat memiliki budaya yang menjadi identitasnya masingmasing. Selain itu, budaya menjadi tanda pengenal bagi setiap manusia dipengaruhi pula oleh tempat di mana dia dibesarkan dan dididik. Adapun enam dimensi budaya menurut Hofstede sebagaimana yang ditampilkan pada Gambar 3, yaitu: individualistic vs collectivisic, ndividualistic vs collectivisic, uncertainty avoidance, power distance, time perspective, dan indulgence $v$ s restraint. Enam dimensi tersebut ditunjukkan oleh gambar 3 .

Budaya yang berhubungan dengan power

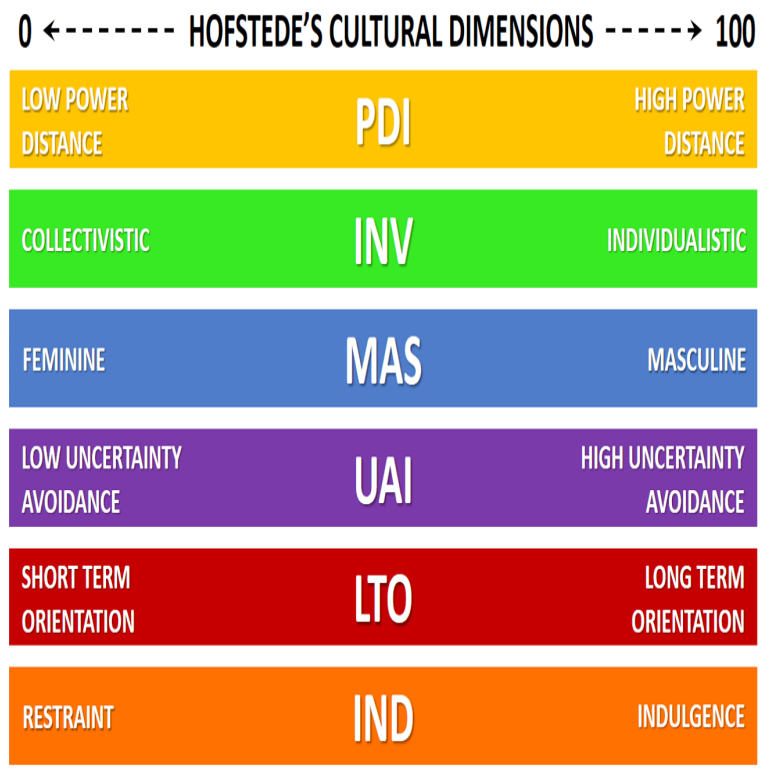

Sumber: Business-to-you, 2017

Gambar 3 Enam Dimensi Budaya Hofstede

distance terkait dengan perilaku komunikasi, yaitu low-context communication dan highcontext communication. Kedua hal tersebut dapat dilihat dari cara manusia berkomunikasi, karena pada dasarnya high-context communication adalah cara mengekspresikan pesan yang secara langsung atau dengan kata lain tidak ada hal tertentu yang disembunyikan. Sebaliknya, justru budaya low-context communication memperlihatkan suatu cara penyampaian pendapat dengan banyak hal yang disandikan atau pesan yang diberikan hanya secara sekelumit saja dari bagian yang lebih besar. (Husna, 2015)

Pada dimensi kedua yakni individualistic vs collective Hofstede (2010) mencoba membawa cara berpikir kita bahwa akar dari perbedaan antara budaya adalah isu dasar dalam kehidupan sosial manusia, dimana individu memiliki perannya sendiri dan kelompok juga demikian. Hofstede menegaskan bahwa kelompok atau collective di sini bukan berbicara dalam ranah politik yang menjadi motor untuk menguasai manusia, tetapi bersifat power of the group.

Dimensi ketiga adalah feminine. Feminine diharapkan tidak dipahami secara harfiah karena feminine yang dimaksudkan adalah untuk mengenali budaya nasional di mana utamanya melalui nilai-nilai yang terkandung dalam budaya tersebut. Pada gilirannya nilai-nilai tersebut bertujuan untuk diklasifikasikan lebih cenderung bersifat feminine atau masculine. Oleh karena itu, dimensi kedua ini hadir tidak untuk dilihat sebagai sebuah label gender tetapi untuk membantu mengidentifikasi budaya yang hadir sebagai bagian dari hidup manusia (Hofstede, 2010).

Penghindaran Ketidakpastian (uncertainty avoidance) merupakan penjelasan mengenai cara masyarakat dalam suatu kelompok berusaha untuk beradaptasi dalam situasi yang tidak terstruktur atau keadaan yang tidak pasti. Tercermin dua sisi, yaitu toleransi budaya atau intoleransi ketidakpastian. Dalam budaya penghindaran ketidakpastian yang tinggi, situasi yang tidak pasti, ambigu, berisiko atau tidak terdefinisi dipandang mengancam dan dihindari dengan segala cara. Dalam rangka menghindari budaya penghindaran ketidakpastian, risiko seringkali dianggap sebagai komponen alami kehidupan yang dapat menghasilkan peluang (Hasan, 2008)

Dimensi kelima adalah short-term oriented yang ada dalam time perspective. Hofstede (2010) menegaskan bahwa shortterm oriented lebih mengembangkan pada kebijakan-kebijakan di masa lampau dan masa sekarang. Di sisi sebaliknya, long-term oriented mencerminkan kebijakan yang diambil berimplikasi pada masa yang akan datang.

Dimensi keenam adalah restraint. Hofstede (2010) menegaskan bahwa restraint menggambarkan sebuah pendirian atas kepuasaan menjadi hal yang harus dipertahankan dan diatur oleh kekuatan norma sosial. Iklan yang penulis kaji termasuk dalam dimensi restraint, hal ini dikarenakan iklan tersebut menekankan pada kepentingan produk yang dijual. Selain itu, iklan ini pun berfokus pada pencapaian kepada khalayak dimana haruslah diterima dengan baik.

Melalui keempat dimensi ini, penulis dapat 
memahami bahwa iklan yang disajikan kepada khalayak dalam durasi waktu yang singkat, mengandung nilai-nilai penting dari berbagai aspek yang sangat berarti dalam berbagai dimensi kehidupan manusia. Tujuan riset ini diarahkan pada kajian komunikasi lintas kultural melalui pesan yang ditampilkan dalam iklan Mixagrip sebagai sarana penyebaran nilainilai hidup manusia Indonesia yang majemuk dikonstruksikan melalui berbagai dimensi budaya sebagai refleksi.

Merawat keragaman suku bangsa Indonesia penting untuk dilestarikan, sejalan dengan kajian etnobiologi yang dilakukan Iskandar (2016). Pengetahuan ekologi dan biologi lokal merupakan aset yang potensial dari ragam masyarakat untuk pembangunan Indonesia berkelanjutan. Hidayat (2017) telah menunjukkan kearifan lokal yang mampu menyajikan kebinekaan dari ragam suku di Lampung melalui identitas atribut Siger. Selain itu, aset serupa yang disebut oleh Melina (2016) sebagai "keragaman sosial budaya" ini dipandang mampu meningkatkan kesejahteraan masyarakat dan kualitas manusia. Hal ini dapat dicapai bila terdapat pembangunan budaya di Indonesia.

\section{METODE PENELITIAN}

Riset ini bersandar pada paradigma interpretif dengan pendekatan kualitatif untuk melihat iklan Mixagrip sebagai bagian dari komunikasi interkultural. Paradigma interpretif dapat dipahami sebagai paradigma yang tidak hanya melihat budaya sebagai sebuah realitas yang mempengaruhi dan masuk ke dalam kehidupan manusia. Akan tetapi, lebih dari pada itu, pendekatan interpretif dapat dipahami bahwa manusia mampu bertindak atas suatu realitas serta melakukan konstruksi terhadap realitas tersebut. Oleh karena itu, perilaku manusia tersebut tidak dapat dipandang sebagai sesuatu yang telah ditentukan atau pun sesuatu yang telah diramalkan (Martin dan Nakayama, 2010). Pemahaman tentang paradigma intepretif ini secara tidak langsung telah membawa cara pandang untuk melihat budaya sebagai bagian dari komunikasi yang menjadi sarana untuk tetap berdasarkan pada realitas tetapi juga untuk menciptakan perspektif baru setiap orang. Paradigma interpretif sangat membantu penulis untuk menemukan beberapa komponen yang ada di dalam iklan tersebut. Komponenkomponen tersebut akan dijelaskan pada bagian hasil dan pembahasan.

Dalam paradigma interpretif, Martin dan Nakayama (2010) menegaskan bahwa ada rhetorical approach sebagai salah satu cara untuk menafsirkan sebuah objek penelitian. Adapun produk budaya sebagai objek penelitian yang dimaksud, dapat berupa tulisan ataupun lisan sesuai dengan konteks budaya di masyarakat. Setiap peneliti akan memiliki interpretasi yang berbeda-beda terhadap suatu objek riset, termasuk iklan Mixagrip versi Keragaman Budaya yang sedang penulis kaji. Iklan ini menggerakkan penulis untuk melihat karya tersebut sebagai bagian dari artefak budaya yang layak dikaji dari perspektif komunikasi lintas kultural, dimana nilai-nilai dalam suatu unsur budaya direfleksikan melalui pesan yang terkandung pada isi teks.

Penulis menggunakan metode analisis isi kualitatif, dimana metode ini lebih banyak dipakai untuk meneliti dokumen berupa teks, gambar, simbol, dan sebagainya untuk memahami budaya dari suatu konteks sosial tertentu. Analisis isi kualitatif menurut Mayring (2000) merupakan suatu sistematika untuk menganalisis teks yang akan dikembangkan oleh penulis dengan tahapan-tahapan dan prosedur yang telah disesuaikan. Analisis isi mendefinisikan dirinya sebagai suatu kerangka pendekatan empiris dan metodologis yang dikendalikan dalam konteks komunikasi, mengikuti langkah demi langkah untuk mendapatkan hasil yang terbaik. Mayring (2003) menekankan tujuh ide dasar analisis konten secara kualitatif, antara lain: (1) masuk ke dalam model komunikasi; (2) berbasis aturan sistematis; (3) memiliki berbagai kategori analisis; (4) subyek dominan daripada teknik; (5) studi terdahulu sebagai verifikasi instrumen; (6) berpijak pada kerangka teoretis; (7) keandalan analisis pada interpretasi triangulasi.

Tujuh ide dasar analisis isi kualitatif tersebut yang membedakan dari analisis teks interpretif maupun studi hermeneutik (Mayring, 2002). Mayring telah mengembangkan model sekuensial dari analisis isi kualitatif dan mengemukakan tiga prosedur analisis yang dapat dilakukan baik secara independen maupun kombinasi, tergantung pada pertanyaan penelitian tertentu. Adapun tiga hal tersebut antara lain: abstraksi, eksplikasi, dan 
strukturisasi (Mayring, 2003)

Abstraksi merupakan suatu upaya untuk mengurangi materi sedemikian rupa, sehingga hanya konten penting yang dipertahankan. Sebuah kumpulan teks dapat dikelola dengan baik melalui abstraksi yang tidak menghilangkan esensi materi aslinya. Teks diparafrasakan, kemudian berusaha digeneralisasi untuk diabstraksikan dan dikurangi. Perlakuan abstraksi teks berupa parafrase atas pesan yang terkandung dalam iklan audio-visual Mixagrip versi Keragaman Budaya. Sejumlah potongan adegan yang ditampilkan iklan dikelola sebagai unit analisis yang dikaji melalui perspektif komunikasi lintas kultural.

Eksplikasi melibatkan penjelasan, klarifikasi dan menganotasi atau menambahkan keterangan untuk memperdalam materi. Anotasi materi dapat ditempuh melalui penjelasan penulis berdasarkan kutipan literatur yang memadai, dapat berbentuk glosarium, ataupun berupa catatan kaki. Langkah pertama, definisi lexico-grammatical ditelusuri dari penggunaan atau pilihan kosakata (leksikon) dan penataan bahasa yang digunakan (gramatikal). Jika kedua hal tersebut telah ditentukan, maka bahan eksplikasi ditetapkan, kemudian diikuti oleh analisis konteks sempit, dan analisis konteks yang meluas. Hasil akhir dari proses ini terwujud suatu "eksplikasi parafrase" dibuat dari bagian teks tertentu, kemudian penjelasan-penjelasan tersebut dihubungkan dengan keseluruhan konteks. Pola eksplikasi parafrase terhadap analisis konteks sempit beberapa adegan iklan Mixagrip versi Keragaman Budaya, kemudian dilanjutkan dengan konteks yang lebih luas seperti tema besar yang diangkat oleh Kalbe.

Strukturisasi sesuai dengan prosedur yang digunakan dalam analisis konten klasik, sering juga dipandang sebagai teknik analisis konten yang paling krusial. Tujuannya untuk menyaring struktur tertentu dari materi, karena teks umumnya terstruktur sesuai isi, bentuk dan skala tertentu. Tahap pertama adalah penentuan unit analisis, setelah itu dimensi strukturisasi akan dibentuk berdasarkan kerangka teoretis sebagai landasan sistem kategorisasi data yang telah ditetapkan. Adapun kerangka teoritis mengacu pada Dimensi Budaya Hofstede, dilengkapi dengan konsep nilai-nilai kehidupan manusia untuk memperkaya temuan riset.

Dalam penilaian pertama dari analisis teks dengan pendekatan kualitatif jenis data ditandai, kemudian penelitian diproses dan diekstraksi. Jika perlu, sistem kategorisasi diperiksa ulang dan direvisi, ditujukan untuk penilaian ulang terhadap teks. Tahapan akhir hasil analisisnya diproses dalam interpretasi yang komprehensif.

\section{HASIL DAN PEMBAHASAN}

Pesan yang tersaji melalui iklan Mixagrip menjadi perhatian utama penulis dalam menguak kekayaan budaya Indonesia disajikan dalam bentuk produk audio-visual. Terdapat beragam nilai yang dilahirkan, nilai ekonomi, nilai seni, nilai bahasa, dan nilai sosial. Lingkungan sosial menjadi ruang bagi tumbuhnya nilai sosial, dimana terjadi interaksi antar manusia. Interaksi tersebut termasuk kelompok-kelompok tertentu, dan simbol. Selain itu, interaksi sosial juga dapat dilakukan melalui tutur kata, jabat tangan, bahasa isyarat, atau bahkan tanpa kontak fisik. (Sarinah, 2016).

Refleksi interaksi sosial sebagaimana relasi antar manusia banyak ditemui dalam berbagai media, salah satunya iklan Mixagrip yang menjadi representasi masyarakat Indonesia. Pola-pola yang dihadirkan kepada khalayak ramai merupakan bagian dari tindakan komunikatif.

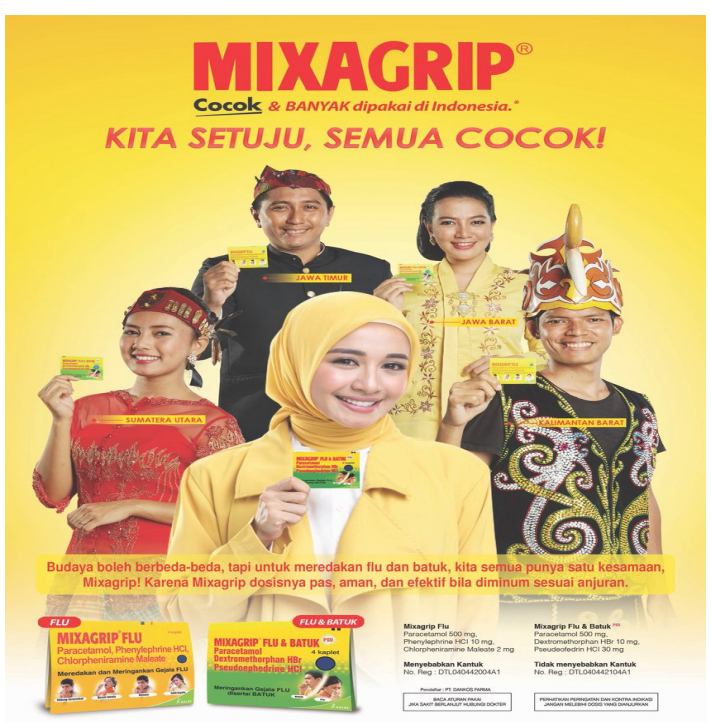

Sumber: SCTV, 2017

\section{Gambar 4 Poster Iklan Mixagrip}

Iklan Mixagrip yang ditunjukkan dalam Gambar 4 ini memperlihatkan kekayaan budaya Indonesia. Hal ini merupakan relasi sosial yang terjalin dalam proses komunikasi antar budaya, ada relasi yang terjalin melalui ragam 
upaya saling mengenal budaya lain. Iklan yang tersaji dalam wujud poster konsisten dengan iklan audio visual yang ditayangkan sebagai Television Video Comercial (TVC).

Tampak pada iklan ini ragam budaya yang direpresentasikan oleh para aktor ditampilkan dengan seimbang, tanpa adanya perbedaan kelas sosial sebagaimana yang menjadi komoditas iklan pada umumnya pada riset Budiasa (2016). Artinya, dalam iklan tersebut tidak diperlihatkan seberapa kaya atau miskin para pemeran iklan, seberapa tinggi pendidikan para pemeran, seberapa tinggi kedudukan seseorang. Di sisi lain, iklan memperlihatkan relasi sosial yang holistik dari berbagai daerah dengan latar kearifan budaya lokal yang berbeda-beda. Hal ini utamanya terlihat pada Gambar 5, dimana berbagai suku bangsa dipaparkan sejajar bersama-sama mengepalkan tangan.

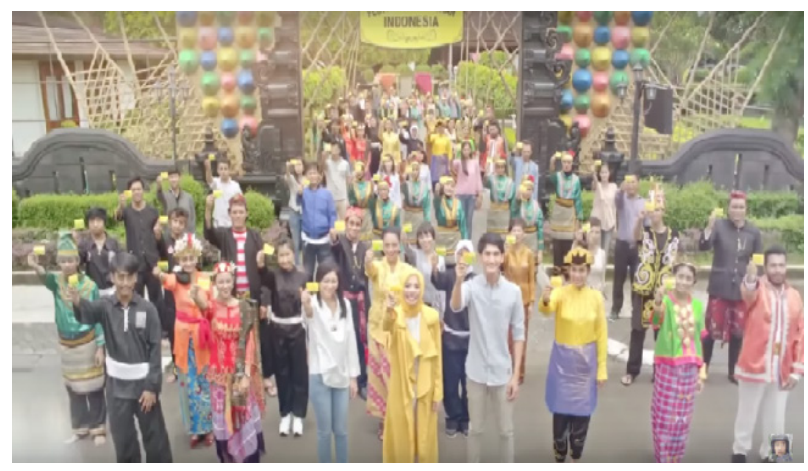

Sumber: Mixagrip Cocok, 2017

\section{Gambar 5 Potongan shot durasi 00: 47}

Tekad bulat ditunjukkan untuk kedaulatan persatuan ragam budaya daerah nasional. Bertolak belakang dengan bentuk dominasi kebudayaan yang senantiasa ditempuh melalui 'cara klasik' penyeragaman budaya di era Orde Baru (Anderson, 2006).

Salam (2014) mengusulkan integrasi horizontal di bidang sosial untuk menghindari terjadinya disintegrasi bangsa. Ditopang pula oleh tiga upaya, yaitu: nasionalisme, pembangunan ekonomi, dan menghilangkan diskriminasi. Wujud integrasi ketiganya secara nyata dapat disimak adalah upaya Mixagrip menyajikan corak keragaman budaya Indonesia. Iklan ini mampu memberikan good effect bagi khalayak penonton, karena menanamkan nasionalisme, mengemas ragam budaya sebagai aset membangun Indonesia, sekaligus menampilkan kesetaraan suku bangsa.

Jika dilihat dengan menggunakan perspektif masculinity dari Hofstede, maka iklan ini menjadi karya yang memperlihatkan budaya dengan mengandung sifat feminine dibandingkan corak masculine. Pada gambar 6 telah menunjukkan kesetaraan gender, utamanya memperlihatkan perempuan turut serta mengikuti adegan pencak silat.

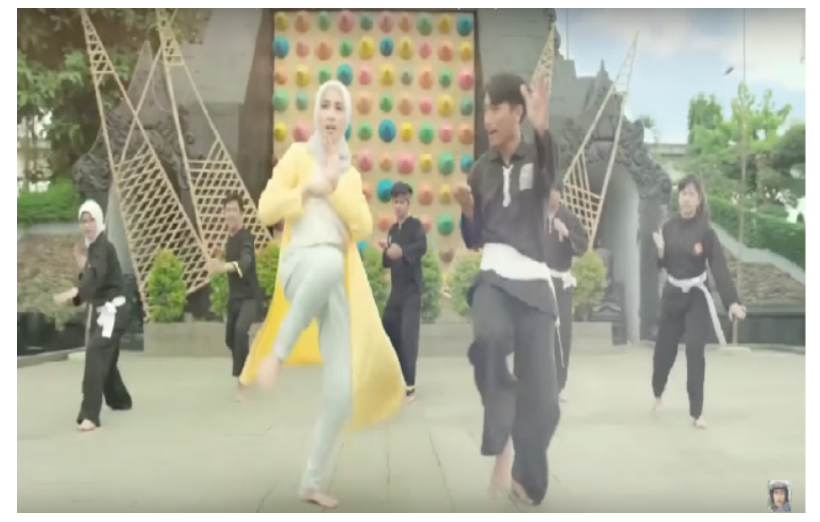

Sumber: Mixagrip Cocok, 2017

Gambar 6 Potongan shot durasi 00: 19

Pencak silat selalu identik dengan lakilaki, namun dalam iklan ini perempuan pun turut mengambil bagian. Selain itu, bila dirunut berdasarkan eksplikasi konten ditemukan konteks budaya dan religi masyarakat Indonesia secara luas. Hal ini dapat disimak pada ulasan Gristyutawati (2012), dimana Pencak Silat disebutkan sebagai hasil budaya manusia Indonesia untuk membela, mempertahankan, eksistensi atau kemandirian dan integritasnya secara manunggal terhadap lingkungan hidup atau alam sekitarnya untuk mencapai keselarasan hidup guna meningkatkan iman dan Taqwa.

Dalam memaparkan dimensi masculinity, Utama (2017) menegaskan bahwa sifat femininitas lebih menyinggung preferensi untuk kerja sama, kerendahan hati, menjaga yang lemah, kualitas hidup dan berorientasi pada konsensus. Dimensi ini menitikberatkan pada "kita (we)" dibanding "saya (I)". Artinya tidak ada kepentingan pribadi yang menjadikan budaya sebagai pelindung. Lebih dari itu, terdapat kepentingan bersama bagi setiap individu hidup dalam relasi sosial yang saling menerima dan menghormati, sehingga menjadi satu kesatuan yang bernilai walaupun dengan latar belakang yang berbeda-beda.

Tidak sebatas itu, dalam beberapa scene juga terlihat bahwa peningkatan dan penjagaan pada sebuah nilai sosial akan menghasilkan 


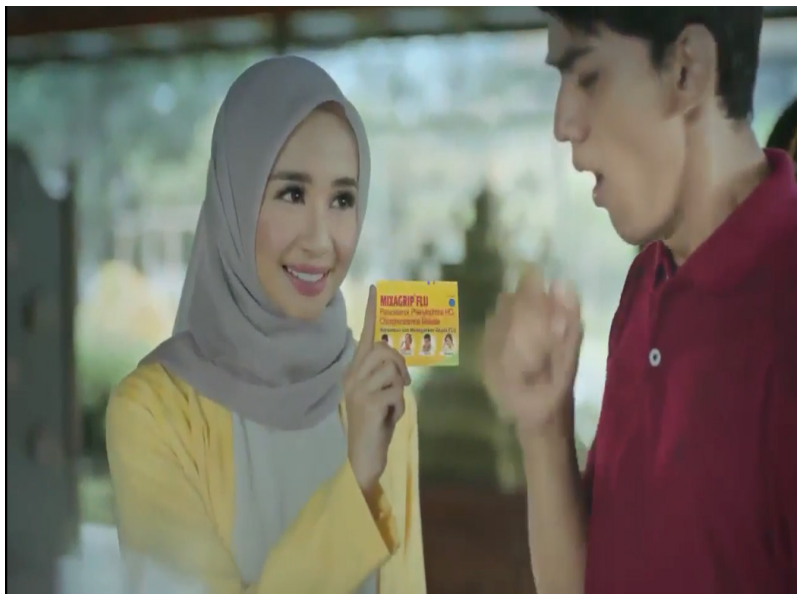

Sumber: Mixagrip Cocok, 2017

Gambar 6 Potongan shot durasi 00: 30

tindakan yang positif. Dalam iklan ini, terlihat ada dua pemeran iklan yang tampak pada gambar 7 maupun gambar 8 yang mengalami sakit dan keberadaannya sedang ada di tengahtengah banyak orang yang hadir dengan menggunakan pakaian adat yang berbeda-beda. Mereka yang muncul dalam scene berasal dari latar belakang budaya yang berbeda memiliki tujuan yang sama, yakni memberikan obat atau produk sebagai objek yang dijual kepada kedua pemeran yang sakit dengan tujuan dapat menyembuhkan.

Melalui adegan sederhana seperti itu, secara tidak langsung para pemeran telah menghidupkan salah satu nilai sosial rasa untuk saling membantu. Jika berbicara tentang rasa atau tindakan untuk saling membantu sudah menjadi hal yang kerap terjadi dalam kehidupan sehari-hari. Secara lebih spesifik tindakan membantu akan berbeda konteksnya jika dicurahkan kepada orang yang berbeda latar belakang sosialnya, baik dari sisi agama, suku, bahasa, pendidikan, atau lain sebagainya. Hal ini dimungkinkan karena manusia cenderung memiliki kemudahan berinteraksi dengan manusia lain dengan latar belakang atau lingkungan yang sama. Terlepas dari hal tersebut, iklan ini ingin menegaskan bahwa terdapat unsur mendorong diri untuk tidak menjadikan kesulitan sebagai sebuah alasan untuk menghilangkan nilai sosial.

Ketika konten iklan ini dianalisis, kemudian dielaborasi dengan teori Dimensi Budaya Hofstede maka dapat terlihat dengan jelas bahwa nilai sosial secara tidak langsung telah dimunculkan pada iklan tersebut. Hofstede

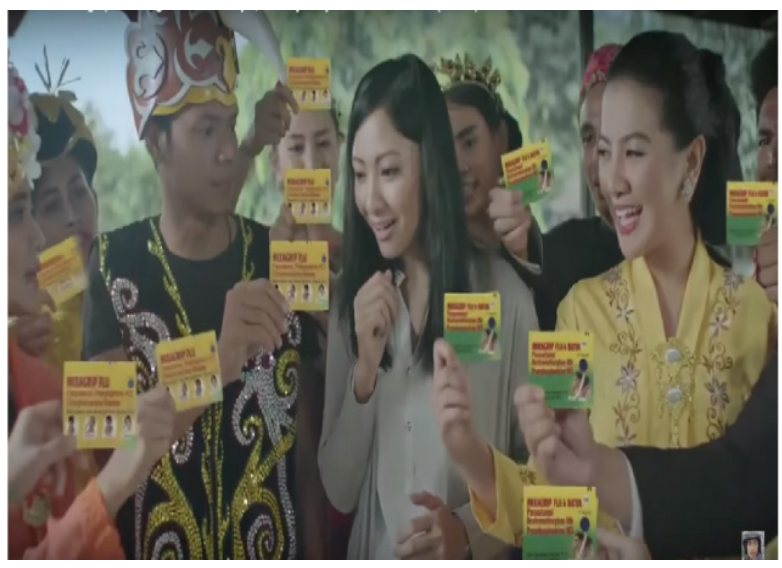

Sumber: Mixagrip Cocok, 2017

Gambar 7 Potongan shot durasi 00: 32

mengemukakan bahwa jika kita bersentuhan dengan dimensi masculinity, maka kita dapat melihat relasi menjadi sangat penting. Tidak sekadar relasi, tetapi menjadikan hidup lebih berkualitas. Hofstede menyadarkan kita untuk dapat memahami bahwa pendekatan femininity ini pun melihat seluruh lapisan masyarakat tidaklah sebagai objek dan hanya mementingkan kepentingan individu. Di sisi lain lebih dari pada itu, Wulantari (2012) menyebutkan pendekatan femininity ini melihat dari perspektif peran gender sosial yang jelas berbeda, dimana feminitas dipandang lebih sederhana, lembut, dan peduli dengan kualitas hidup.

Tidak hanya sampai pada sifat peduli terhadap kualitas hidup, namun pendekatan ini juga memandang laki-laki dan perempuan (dalam hal ini seluruh lapisan masyarakat) untuk dapat bertanggung jawab, saling memberikan perhatian satu dengan yang lain, menjadi lembut dan tidak memperlihatkan kekerasan, namun tetap bersikap tegas. Dimensi masculinity menjadi begitu menarik dalam kajian nilai sosial karena terciptanya kesejahteraan dalam pendekatan femininity sebagai bentuk dari idealisme sosial serta tindakan saling menolong saat yang lain membutuhkan.

Melihat pendekatan feminine ini dalam kajian iklan Mixagrip pada tataran eksplikasi konten secara kualitatif Mayring, maka jelas terlihat bahwa konteks yang dihadirkan oleh iklan dan konteks berpikir Hofstede memiliki relevansi yang kuat. Hubungan tersebut terlihat ketika iklan ini menyajikan eratnya budaya dalam kemajemukan di Indonesia, dimana keharmonisan yang disajikan dalam 
beberapa scene. Hubungan antara teori dan iklan Mixagrip menjadi salah satu bukti bahwa budaya keberagaman yang menjadi realitas sosial masyarakat Indonesia adalah anugerah yang patut disyukuri karena menjadi salah satu bentuk keindahan bagi bangsa ini.

Nilai sosial ini juga dapat dilihat dengan dimensi collectivist, dimana pendekatan ini menekankan sumber daya yang ada perlu dirasakan oleh semua orang. Tidak sebatas itu, pendekatan ini pun menitikberatkan pada kepentingan kolektif yang berlaku atas individu. Melihat dimensi ini sebagai konten yang dianalisis secara kualitatif Mayring, maka terdapat keterkaitan antara dimensi collectivist dengan nilai sosial. Keterkaitan antara dimensi ini dengan iklan sangat tampak pada produk Mixagrip yang adalah hasil dari kerja keras sumber daya manusia dapat dirasakan oleh banyak orang dan di sanalah tercipta nilai sosial yang menjadi bagian dari budaya bangsa ini.

Penulis melihat dimensi collectivist Hofstede menunjukkan bahwa manusia (secara kolektif dalam hal ini direpresentasikan perusahaan yang memroduksi produk Mixagrip dengan masyarakat sebagai simbiosis mutualisme. Artinya, terdapat unsur saling membutuhkan atau saling bergantung satu dengan yang lainnya. Di satu sisi, manusia secara kolektif membutuhkan masyarakat untuk meningkatkan produktivitas hingga nilai jual dengan menjadi konsumen. Di sisi lain, justru masyarakat membutuhkan perusahaan (secara kolektif) untuk memenuhi kebutuhan kesehatan mereka. Nilai sosial yang saling membutuhkan ini merupakan salah satu bukti bahwa budaya di Indonesia yang majemuk mampu bertahan hidup dengan tetap saling membutuhkan satu dengan yang lainnya.

Dimensi lainnya yang dapat dikaji dalam nilai sosial adalah high power distance. Pendekatan ini menekankan bahwa rasa hormat sebagai kebajikan seumur hidup. Rasa hormat di sini lebih ditekankan pada hormat antar manusia, suku, budaya, agama, yang kemudian menyatu dalam kehidupan masyarakat sosial. Hal ini terlihat dalam iklan Mixagrip, di mana penerimaan terjadi ketika beragam suku, budaya, agama, dan latar belakang setiap individu ada dalam "ruang" yang sama. Rasa hormat yang terlihat antara satu dengan yang lainnya dalam iklan Mixagrip merupakan "pintu masuk" terciptanya keharmonisan sosial yang menjadi salah satu bentuk kebajikan setiap individu.

Setelah nilai sosial berusaha untuk dipaparkan, nilai kedua yang tidak dapat dihilangkan begitu saja adalah nilai ekonomi. Mengingat Indonesia pernah berada dalam urutan negara berkembang yang berusaha keras menghadapi krisis ekonomi Terlepas dari pemahaman itu, iklan Mixagrip hadir dengan memperlihatkan bahwa ada nilai ekonomi yang dijual tampak pada gambar 8 .

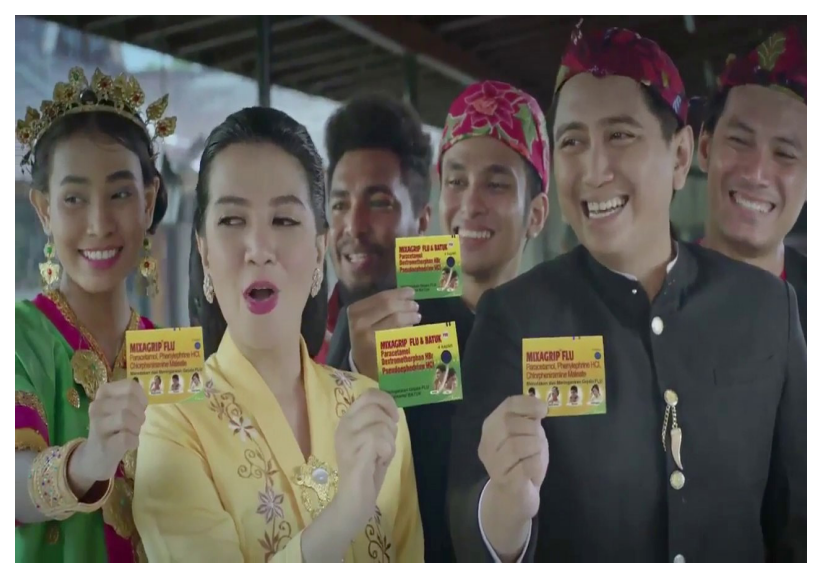

Sumber: Mixagrip Cocok, 2017

Gambar 8 Potongan shot durasi 00: 33

Seperti yang kita ketahui sejauh apa pun perbincangan tentang ekonomi atau sebagus apa pun iklan yang dibuat, maka terdapat unsur kapitalisme yang juga sangat berkaitan erat dengan ekonomi. Unsur kapitalisme terjadi karena berbagai kepentingan yang melatar belakangi terjadinya penjualan sebuah produk, dan Mixagrip menjadi salah satu di dalamnya. Di sisi lain, penulis melihat nilai ekonomi dari iklan ini dengan perspektif yang berbeda, yakni produk yang dijual dapat dijangkau oleh seluruh lapisan masyarakat dengan harga yang merakyat. Berbagai redudansi terjadi, utamanya pada gambar 6 hingga gambar 9 pemirsa pariwara ini secara tidak langsung diterpa produk ini bertubi-tubi untuk diingatkan bahwa produk Mixagrip ini direkomendasikan oleh berbagai penjuru maupun daerah pelosok Indonesia.

Sadar atau tidak, pemahaman seperti ini telah menguatkan nilai sosial dengan tidak memandang pada khalayak dalam kelas tertentu. Di sisi lain, target produk ini adalah seluruh lapisan masyarakat, yang semakin memperkuat relasi sosial. Cara pandang terhadap nilai ekonomi seperti ini terlalu sederhana, tetapi penting untuk dipertimbangkan bahwa melalui 
pemasaran yang menjangkau seluruh lapisan masyarakat hingga sampai pada pelosok Indonesia, maka nilai jual yang diterima pun tidaklah sedikit, mengingat produk yang dijual merupakan salah satu kebutuhan masyarakat secara menyeluruh.

Penulis melihat bahwa dalam nilai ini terdapat dimensi restraint milik Hofstede, proses abstraksi menekankan pada kebutuhan. Selain itu, pendekatan ini juga menitikberatkan pada kepentingan status dari objek yang dijual. Melihat pendekatan ini dan nilai ekonomi dari iklan tersebut dengan menggunakan pendekatan kualitatif Mayring, maka terdapat keterkaitan antara keduanya. Iklan Mixagrip dengan latar belakang perusahaan yang memproduksinya membutuhkan peningkatan nilai jual, sedangkan masyarakat membutuhkan produk sebagai salah satu sumber kesehatannya. Nilai ekonomi yang hadir lebih mentikberatkan pada kepentingan perusahaan. Pada kenyataannya aspek penonjolan budaya jauh lebih mendominasi, dibandingkan nilai ekonominya.

Nilai ketiga yang terdapat dalam iklan Mixagrip adalah nilai seni. Berbicara tentang seni, maka akan banyak sekali pengertian, pendapat, dan spekulasi tentang keberadaan dan makna dari seni itu sendiri. Seni dapat dinikmati di mana saja termasuk unsur budaya yang terkandung di dalamnya. Iklan yang dikaji menampilkan cukup banyak kesenian, yakni terdapat seni tari Saman khas Provinsi Daerah Istimewa Nangroe Aceh Darussalam (NAD) pada gambar 10 .

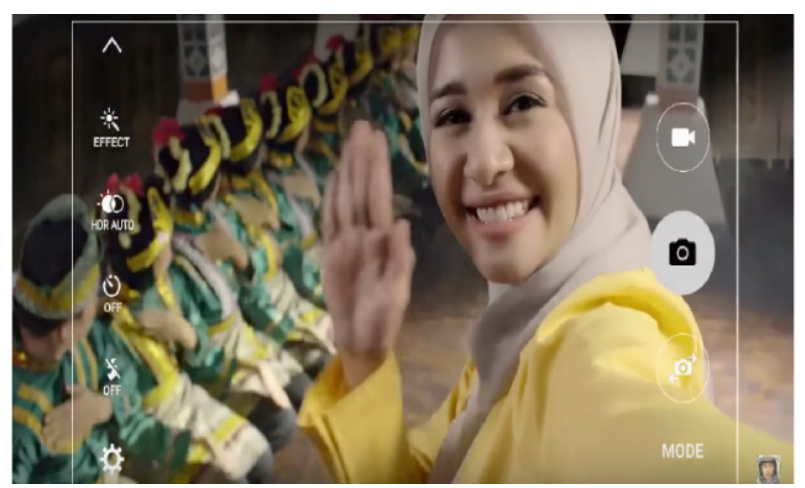

Sumber: Mixagrip Cocok, 2017

Gambar 10 Potongan shot durasi 00: 11

Seni lukis berupa batik tulis menggunakan canting sebagai ciri khas kebiasaan para pengrajin batik di Provinsi Jawa Tengah maupun Daerah Istimewa Yogyakarta (DIY) diperlihatkan secara jelas pada gambar 11,

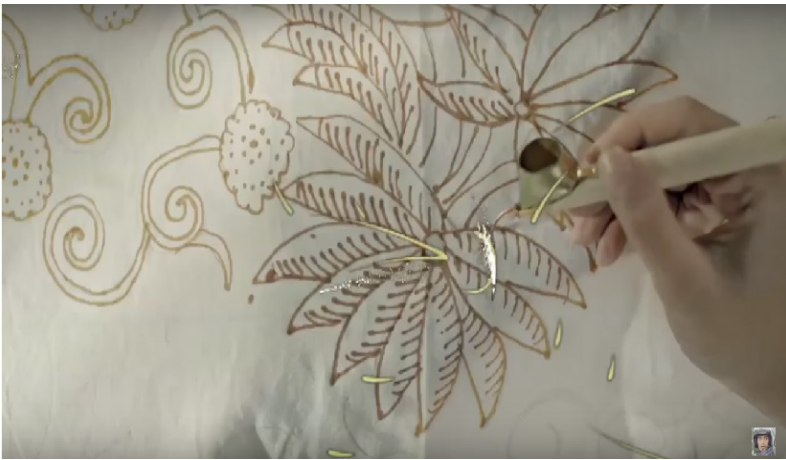

Sumber: Mixagrip Cocok, 2017

Gambar 11 Potongan shot durasi 00: 11

bahkan kesenian serupa membentang dari pesisir pantai Utara Provinsi Jawa Timur hingga Jawa Barat.

Selain seni tari dan seni lukis, seni ukir terlihat pada gambar 12 berupa karya gapura.

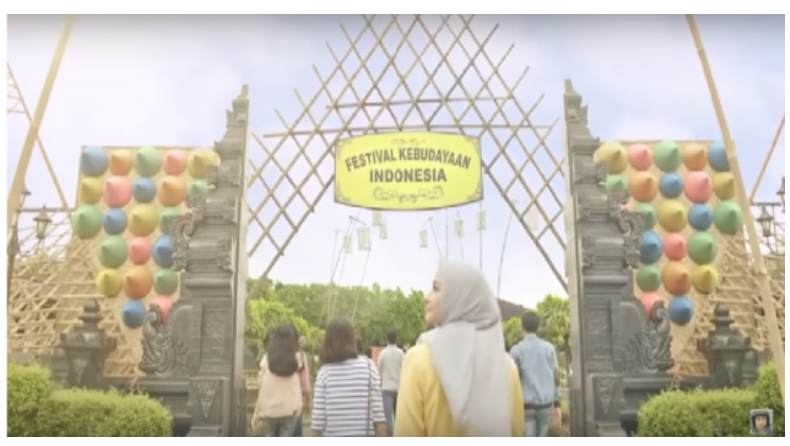

Sumber: Mixagrip Cocok, 2017

Gambar 12 Potongan shot durasi 00: 01

Triyanto (2014) menghimbau bahwa budaya dan seni menjadi dua hal yang tidak dapat dipisahkan, justru kedua hal yang dipahami berbeda ini merupakan satu kesatuan yang mendorong setiap manusia untuk mengembangkan potensi yang ada dalam diri mereka. Seni yang dikemas dalam budaya seharusnya berfungsi untuk mengantarkan manusia dalam mengembangkan seluruh potensinya secara komprehensif (Triyanto, 2014).

Pemahaman seperti ini menarik untuk dilihat sebagai bentuk penyadaran oleh seluruh manusia bahwa budaya dan seni hadir tidak hanya untuk menunjukkan bahwa setiap tempat atau negara memiliki identitas. Akan tetapi, lebih dari pada itu budaya dan seni berkolaborasi dalam menunjang kompetensi dalam berkarya. Penulis melihat kolaborasi ini sebagai bagian dari menghidupkan kekayaan yang sudah dimiliki. Artinya, manusia yang dihadirkan 
dalam dunia dengan kekayaan potensi berpikir dan bertindak mampu membuat budaya menjadi lebih hidup dan bernilai. Budaya dan seni hadir untuk memperkaya manusia, sedangkan manusia hadir untuk menghidupkan budaya dan seni.

Triyanto dalam karyanya mengutip pemikiran Hobel (1986) bahwa dalam berbagai penelitian lintas budaya, seni akan terus tampak dengan memperlihatkan coraknya yang khas (Triyanto, 2014). Pengertian yang demikian terlihat jelas dalam iklan yang penulis kaji, di mana terdapat corak batik sebagai salah satu perwujudan bentuk seni dari budaya Jawa dan tari saman sebagai salah satu perwujudan dari budaya Aceh.

Jika ditelaah lebih dalam lagi dari seniseni yang melekat pada budaya, maka kita akan mendapatkan sebuah makna estetika yang kemudian memberikan kebebasan kepada setiap penikmat untuk menafsirkan dan merefleksikan berbagai hal yang mereka lihat dari seni tersebut. Setiap budaya yang begitu banyak di Indonesia memiliki makna dan pesan yang dinyatakan dalam karya seni. Masih tetap mengacu pada karya yang dibuat oleh Triyanto (2014) bahwa seni dan budaya memiliki latar belakang dalam mengonstruksi dasar dari kedua hal ini. Seni hadir dengan estetika yang lahir dari pengetahuan, kreativitas, dan imajinasi manusia. Di sisi lain budaya lahir dari paham akan bentuk-bentuk kebudayaan pada masa lampau yang terus dihidupkan bahkan dikontekstualisasikan di masa sekarang (Triyanto, 2014).

Pergeseran paham yang terus diperkaya tentang seni dan budaya akan terus terjadi dari generasi ke generasi. Hal ini dikarenakan dengan berkembangnya zaman, maka perkembangan kreativitas akan semakin diperbaharui sesuai dengan minat dan konteks yang sedang berlangsung. Pengalaman dan imajinasi akan terus lahir, sehingga budaya akan terus diekspresikan.

Dimensi yang terlihat dalam iklan Mixagrip yang kemudian dipandang dalam nilai seni adalah pendekatan short-term oriented. Dimensi ini menekankan pada perhatian akan tradisi. Analisis konten menunjukkan dengan jelas dalam iklan ini terdapat upaya untuk tetap mempertahankan tradisi. Seperti yang kita ketahui bersama bahwa tradisi negara ini tidak dapat terlepas dari seni tari, seni ukir, seni membatik, dan bahkan masih banyak seni-seni lainnya.

Nilai Bahasa atau nilai keempat merupakan bagian penting yang tidak dapat terlepas dari iklan yang penulis kaji, yakni bahasa. Bahasa menjadi salah satu kekayaan manusia dalam melakoni setiap hal. Iklan Mixagrip yang menjadi objek untuk dibedah hadir dengan memperlihatkan nilai bahasa kepada khalayak. Memang, durasi iklan tersebut tidaklah terlalu panjang, oleh karenanya bahasa yang dikemukan melalui penuturan sang artis pun sangat singkat. Seperti yang sudah dijelaskan sedikit dalam latar belakang bahwa ada penuturan yang menarik untuk dikaji yakni "dari Sabang sampai Merauke, kita punya budaya yang berbedabeda. Kalau untuk flu dan batuk, kita punya satu kesamaan".

Putri (2016) menggunakan perspektif komunikasi pemasaran, melihat pemakaian bahasa seperti itu menjadi salah satu strategi pemasaran untuk dapat menggugah minat dan keinginan khalayak konsumen. Di sisi lain, penulis mencoba menelaah kembali dan melihat bahwa pemakaian bahasa seperti itu merupakan ajakan untuk melihat Indonesia yang sebesar dan sekaya ini sebagai satu kesatuan. Indonesia punya kesamaan dan menjadi satu kesatuan. Kesamaan paham bahwa kemajemukan yang kental di Indonesia tidaklah menjadi persoalan, justru dengan kesamaan paham inilah, Indonesia dapat memperlihatkan kepada dunia akan kekayaan sebuah negara. Tidak hanya itu, Indonesia juga memiliki kesamaan tujuan berupa perwujudan toleransi. Bahasa mampu mengubah pemahaman seseorang, mengubah cara berpikir, mengubah imajinasi, bahkan bisa menimbulkan banyak spekulasi tentang apa yang disajikan.

Ahmad Mujib (2009) mengutip pemikiran salah satu tokoh yakni Masinambow menyebutkan bahwa bahasa dan budaya merupakan dua sistem yang melekat pada manusia. Hal ini dikarenakan kebudayaan merupakan sistem yang mengatur interaksi manusia, sedangkan bahasa merupakan sistem yang berfungsi sebagai sarana untuk mewujudkan interaksi tersebut

Bertolak dari pemahaman di atas, maka budaya "mengadakan" bahasa, dan bahasa "mengadakan" budaya. Dengan kata lain, kedua unsur ini saling membutuhkan, saling bekerja sama, dan saling melengkapi untuk kepentingan 
setiap unsur. Terdapat konstruksi pemikiran akan salah satu budaya toleransi terhadap kemajemukan harus dimiliki oleh masyarakat Indonesia. Tidak hanya keberagaman budaya, tetapi juga keberagaman agama serta aliran kepercayaan. Memang, tidak diperlihatkan simbol-simbol agama dalam iklan tersebut, kecuali sang artis yang memakai jilbab. Telah diketahui khalayak ramai bahwa mayoritas masyarakat Indonesia beragama Islam, sehingga representasi seorang muslim di antara beragam agama lain mencerminkan kemajemukan budaya Indonesia. Selain itu, guna menangkal konflik perbedaan agama menjadi sebuah issue yang sangat sensitif di Indonesia.

Segala persoalan yang sedang terjadi dewasa ini dengan melibatkan agama dan budaya, penulis melibatkan iklan sebagai unit analisis hadir untuk mengatasi issue yang memanas di Indonesia. Oleh karena itu, melalui iklan ini konstruksi budaya toleransi dalam masyarakat Indonesia.

Sadar ataupun tidak, kemajemukan yang dihidupkan di Indonesia menjadi salah satu penolong bagi kita manusia untuk berbagi "kasih" kepada sesama yang berbeda, entah secara agama, budaya, atau yang lainnya. Penggunaan istilah "kasih" tidak berkaitan dengan dogma tertentu, melainkan Prijanto (2017) menyebutnya sebagai bagian dari amanat agung perutusan manusia di dunia. Kata "kasih" dapat diartikan sebagai sikap "epoche", dijelaskan oleh Casram (2016) bahwa sikap itu berusaha menghindar dari penilaian subyektif dalam menilai agama tertentu. Iklan Mixagrip dihadirkan juga untuk menolong masyarakat Indonesia memaknai lebih dalam mengenai kemajemukan, keberagaman, dan perbedaan yang semestinya tidak dilihat sebagai sebuah masalah, tetapi sebagai kekayaan yang patut dijaga dan dibanggakan.

Pada dimensi pertama yakni individualistic vs collective Hofstede (2010) mencoba membawa cara berpikir kita bahwa akar dari perbedaan antara budaya adalah isu dasar dalam kehidupan sosial manusia, dimana individu memiliki perannya sendiri dan kelompok juga demikian. Hofstede menegaskan bahwa kelompok atau collective di sini bukan berbicara dalam ranah politik yang menjadi motor untuk menguasai manusia, tetapi bersifat power of the group. Iklan Mixagrip yang digunakan sebagai objek dalam riset ini memperlihatkan budaya yang berkelompok. Hal ini dikarenakan iklan tersebut memperlihatkan bahwa Indonesia yang memiliki banyak budaya dan bahasa hidup dalam hubungan masyarakat yang kuat.

Dimensi kedua adalah masculinity, tidak dilihat sebagai sebuah label gender tetapi untuk membantu mengidentifikasi budaya yang hadir sebagai bagian dari hidup manusia (Hofstede, 2010). Berdasarkan pemahaman terhadap definisi ini, penulis menemukan iklan Mixagrip memperlihatkan kesetaraan gender dan tidak ada yang mendominasi atau cenderung mengacu pada dimensi femininitas.

Dimensi ketiga adalah short-term oriented yang ada dalam time perspective. Hofstede (2010) menegaskan bahwa shortterm oriented lebih mengembangkan pada kebijakan-kebijakan di masa lampau dan masa sekarang. Berdasarkan pengertian tersebut, maka iklan yang penulis analisis bersifat short-term oriented. Hal ini dikarenakan iklan tersebut menekankan pada Bineka Tunggal Ika yang mana menjadi semboyan bangsa Indonesia untuk menunjukkan persatuan dalam keberagaman. Semboyan ini memiliki nilainilai kebenaran terhadap relasi berbangsa dan bernegara, dan hal ini bersifat sangat kental dengan paham short-term oriented.

Dimensi keempat adalah restraint. Hofstede (2010) menegaskan bahwa restraint menggambarkan sebuah pendirian atas kepuasan menjadi hal yang harus dipertahankan dan diatur oleh kekuatan norma sosial. Iklan yang penulis kaji termasuk dalam dimensi restraint, hal ini dikarenakan iklan tersebut menekankan pada kepentingan produk yang dijual. Selain itu, iklan ini pun berfokus pada pencapaian kepada khalayak dimana haruslah diterima dengan baik.

Melalui keempat dimensi ini, penulis dapat memahami bahwa iklan yang disajikan kepada khalayak dalam durasi waktu yang singkat, mengandung nilai penting dari berbagai aspek yang berpengaruh dalam kehidupan manusia.

\section{SIMPULAN}

Berbagai hal yang telah dipaparkan dari iklan Mixagrip, kemudian ditonjolkan dalam analisis konten Mayring mampu menonjolkan nilai kemajemukan. Di sisi lain, melalui kajian dimensi budaya Hofstede terdapat pesan yang ingin dikonstruksikan sebagai bagian yang 
tidak terpisahkan dari kehidupan manusia.

Jarak komunikasi lintas kultural tidak nampak dalam iklan ini, sebab komunikasi setiap pemeran dalam iklan tersebut disajikan secara harmonis meski berlatar belakang budaya yang berbeda satu sama lainnya. Kedekatan itu mencerminkan nilai-nilai kemajemukan yang telah dipaparkan, sehingga memancarkan relasi antar budaya. Bila kondisi ini dapat terjaga dengan baik, maka masyarakat akan terhindar dari interpretasi yang salah atau disebut oleh Abdullah (2003: 1-13) sebagai politik Bhinneka Tunggal Ika. Iklan ini berusaha menyadarkan betapa berharganya memelihara kemajemukan sebagai aset pemersatu bangsa yang telah terkoyak oleh konflik sosial.

Melalui iklan Mixagrip ini, pastinya terbesit target dari perusahaan selaku produsen agar produk yang dijual terpasarkan dan diterima oleh seluruh lapisan masyarakat. Tanpa memandang perbedaan suku, ras, agama, maupun golongan apapun. Pada gilirannya secara eksplisit terbesit harapan untuk meningkatkan penjualan produk, mencapai angka penjualan yang ditetapkan. Lebih dari pada itu, iklan ini justru ingin menghembus nilai kemajemukan disemaikan melalui keragaman budaya nasional, kemudian dilekatkan pada setiap insan manusia Indonesia.

Budaya memberikan nilai kehidupan dalam diri manusia, karena melalui budaya yang tercipta maka keberadaan manusia dalam menciptakan suatu peradaban dapat diakui.

Kalbe melalui iklan ini, secara tidak langsung juga menghimbau kepada seluruh lapisan masyarakat Indonesia agar dapat menanamkan ajaran "kasih" atau sikap "epoche" dalam melestarikan toleransi dalam masyarakat yang majemuk. Tentunya, hal ini dilakukan dengan maksud agar nilai-nilai luhur budaya tidak mati dan hilang begitu saja hanya karena perbedaan.

\section{DAFTAR PUSTAKA}

Abdullah, I. (2003). Politik bhinneka tunggal ika dalam keragaman budaya indonesia, Jurnal Masyarakat Dan Budaya. Vol.5 No.2 dalam https://jmb.lipi.go.id/index. $\mathrm{php} / \mathrm{jmb} /$ article/download/248/226 28 Maret 2018.

Alex, H. R. dkk. (2001). Komunikasi antar budaya. Jakarta: Pusat Penerbitan Univeristas Terbuka.
Anderson, B. 2006. Imagined communites. New York: Verso.

Budiasa, M. (2016). Representasi kelas sosial dalam iklan sosro. Promedia, Vol.II No.2 dalam http://journal.uta45jakarta.ac.id/ index.php/kom/article/download/535/332 diakses 28 Maret 2018.

Business-to-you. (2017). Hofstede's cultural dimensions. Diakses dari http://www. business-to-you.com/hofstedes-culturaldimensions/.

Gristyutawati, A. D., Purwono, E. P., Widodo, A. (2012). Persepsi pelajar terhadap pencak silat sebagai warisan budaya bangsa se-kota semarang tahun 2012. Journal of Physical Education, Sport, Health and Recreation Vol.1 No.3 dalam https://journal.unnes. ac.id/sju/index.php/peshr/article/view/443 diakses 08 Maret 2018.

Hasan, H. H., Rahim, S. A. 2008, "Factors Affective Online Purchasing Behavior. Jurnal Komunikasi”, Malaysian Jurnal Of Communication, Vol.24 dalam http://www. ukm.my/jkom/journal/pdf_files/2008/ V24_1.pdf diakses 01 Maret 2018.

Hidayat, D., Kuswarno, E., Zubair, F., \& Hafiar, H. (2017). Message platform atribut siger lampung di dalam kebhinekaan multikultur. Jurnal Kajian Komunikasi, Vol.5 No.1 dalam http://jurnal.unpad.ac.id/jkk/article/ view/9481/5724 diakses 26 Maret 2018.

Hidayat, D. R., Abdullah, A. (2014). Fenomena iklan baris kesehatan di surat kabar lokal. Jurnal Kajian Komunikasi, Vol. 2 No.2 dalam http://jurnal.unpad.ac.id/jkk/article/ view/7380/3383 diakses 02 Maret 2018.

Hofstede, G. (2010). Culture and organization: software of the mind. United State: Mc Graw Hill.

Husna, A. F. (2015). Analisis website terhadap budaya pendekatan teori hofstede. Jurnal Electronics, Informatics, And Vocational Education (Elinvo), Vol.1 No.1 dalam https://journal.uny.ac.id/index.php/elinvo/ article/download/12814/8982, diakses 07 Maret 2018.

Iskandar, J. (2016). Etnobiologi dan keragaman budaya di indonesia. Umbara: Indonesian Journal of Anthropology.Vol.1 No.1 dalam http://jurnal.unpad.ac.id/umbara/article/ view/9602 diakses 20 Maret 2018.

Martin, J. N \& Nakayama, T. K. (2010). 
Intercultural communication in conext. New York: Higher Education.

Mayring, P. (2000). Qualitative content analysis [28 paragraphs]. Forum Qualitative Sozialforschung/ Forum: Qualitative Social Research, Vol.1 No.2. dalam http:// www.qualitative-research.net/fqs-texte/200/2-00mayring-e.htm, diakses 08 Maret 2018.

(2001). Kombination und integration qualitativer und quantitativer analyse. ForumQualitativeSozialforschung/Forum: Qualitative Social Research, Vol.2 No.1 dalam http://www.qualitative-research.net/ fqs-texte/1-01/1-01mayring-d.htm, diakses 08 Maret 2018.

Mayring, P. (2002). Einführung in die qualitative sozialforschung, eine anleitung zu qualitativem denken. Weinheim: Beltz.

Melina. (2016). Peranan budaya dalam pembangunan manusia indonesia. Dunia Ilmu, Vol.2 No.4 dalam http://www. jurnalmudiraindure.com/wp-content/ uploads/2017/04/peranan-budaya-dalampembangunan-manusia-indonesia.pdf diakses 21 Maret 2018.

Mixagrip Cocok. (2016). Senam bugar (budaya olahraga dan tari) mixagrip. Diakses dari https://www.youtube.com/ watch? $\mathrm{v}=9 \mathrm{rwUOpRPUig}$. .(2017).Keragamanbudaya indonesia. Diakses dari https: //www. youtube.com/watch? $\mathrm{v}=\mathrm{NtAP}$ wrELSHM.

Mujib, A. (2009). Hubungan bahasa dan kebudayaan (perspektif sosiolinguistik)", e-Journal UIN, Vol.8. No.1, dalam http://digilib.uin-suka.ac.id/22578/1/ ahmad $\% 20$ mujib-\%20hubungan $\% 20$ bahasa $\% 20$ dan $\% 20$ kebudayaan $\% 20$ $\% 28$ perspektif\%20sosiolinguistik\%29.pdf, 22 Desember 2017.

Prijanto, J. H. (2017). Panggilan guru kristen sebagai wujud amanat agung yesus kristus dalam penanaman nilai alkitabiah pada era digital. Polygot: A Journal Of Language, Literature, Culture And Education Vol.13(2) dalam https://ojs.uph.edu/index. $\mathrm{php} / \mathrm{PJI} /$ article/view/325.
Putri, P. K. (2016). Aplikasi pendekatanpendekatan persuasif pada riset komunikasi pemasaran iklan melibatkan penciptaan dan penerimaan pesan komunikasi persuasif mengubah perilaku pembelian. Jurnal The Messenger. Vol.8(1) dalam http://journals. usm.ac.id/index.php/the-messenger/article/ view/313 diakses 28 April 2018 .

Sarinah. (2016). Ilmu sosial budaya dasar. Yogyakarta: Deepublish.

Salam, A. J. (2014). Jejak integrasi indonesia dari kilometer nol: melacak akar budaya nasional bangsa. Legitimasi: Jurnal Hukum Pidana Dan Politik Hukum. Vol.3 No.1 dalam https://jurnal.ar-raniry.ac.id/index. php/legitimasi/article/view/337 22 Maret 2018.

SCTV. (2016). Saksikan liputan eksklusif resepsi bella \& emran di \#hotshot bersama \#mixagrip tgl 15 okt 2017 pkl 9.00 Wib \& ikuti kuisnya @mixagripcocok. Diakses dari https://twitter.com/SCTV_/ status/919171472798576641.

Srikhandi, A. (2017). Ditanya rencana nikah bulan depan, laudya chintya bella senyum. Diakses dari https://www.kapanlagi. com/foto/berita-foto/indonesia/ditanyarencana-nikah-bulan-depan-laudyachintya-bella-senyum.html.

Triyanto, (2014). Pendidikan seni berbasis budaya. Imajinasi Jurnal Seni. Vol. VIII. No. 1, dalam https://journal.unnes.ac.id/ nju/index.php/imajinasi/article/view/8879, diakses 22 Desember 2017.

Utama, Y. Y. (2017). Analisis pengaruh budaya dan keluarga terhadap orientasi wirausaha orang muda di indonesia dan malaysia. Modus Vol.29(2) dalam https://ojs.uajy. ac.id/index.php/modus/article/view/1329 diakses 28 April 2018.

Wulantari, R. A. (2012). Konstruksi dan reproduksi maskulinitas kelompok muda urban kelas menengah (studi fenomenologi di antara penonton drama korea selatan). Jurnal Komunikasi Indonesia (JKI) Vol.1(2) dalam http://journal.ui.ac.id/ index.php/jkmi/article/view/7820 28 April 2018 . 